\title{
Factors influencing the chance of cows being pregnant 30 days after the herd voluntary waiting period
}

\author{
E. Löf, ${ }^{\star} \dagger^{1} H$. Gustafsson, $† \ddagger$ and U. Emanuelson* \\ *Department of Clinical Sciences, Division of Ruminant Medicine and Veterinary Epidemiology, Swedish University of Agricultural Sciences, \\ PO Box 7054, SE-750 07 Uppsala, Sweden \\ †Swedish Dairy Association, PO Box 210, SE-101 24 Stockholm, Sweden \\ ‡Division of Reproduction, Swedish University of Agricultural Sciences, PO Box 7054, SE-750 07 Uppsala, Sweden
}

\begin{abstract}
The objective of this study was to study factors affecting a reproductive performance indicator at the cow level adjusted for herd management strategy. Associations between the outcome variable, pregnant or not at the herd voluntary waiting period (VWP) plus 30 $\mathrm{d}$ (pregnant at VWP+30), and the predictor variables were analyzed using a multivariable, generalized estimation equations model that adjusted for clustering of the data at the herd level. The statistical analysis was stratified on parity. In total, 132,721 cows were retained for analyses, of which $29,113(22 \%)$ were pregnant at $\mathrm{VWP}+30 \mathrm{~d}$. Of the nonpregnant cows, 81,483 cows had records of artificial inseminations (AI) and 22,125 cows had no records of AI. The chance of pregnancy was higher for cows of the Swedish Red and for other/crossbreeds compared with Swedish Holstein, for cows from herds with high heat detection efficiency compared with cows from herds with medium and low heat detection efficiency, for cows from herds with long VWP (i.e., $>51 \mathrm{~d}$ ) compared with cows from herds with short VWP $(<51 \mathrm{~d})$, and for cows in freestalls compared with cows in tiestalls. The chance for pregnancy was lower for cows with severe problems at claw trimming compared with cows with no problems at trimming (only for second- and higher-parity cows), for cows that had a record of reproduction-related disease, for cows that had a record of any other disease compared with cows without record, for second- and higher-parity cows with records of dystocia compared with cows with no record of dystocia, for first-parity cows in the group with the highest milk yield compared with first-parity cows in the group with the lowest milk yield, for cows of third and higher parity in the group with the lowest milk yield compared with cows in higher yielding groups, for cows bred in summer compared with those bred in winter-spring (not significant for first-parity cows),
\end{abstract}

Received June 26, 2012.

Accepted October 3, 2013.

${ }^{1}$ Corresponding author: Emma.Lof@svenskmjolk.se and for cows with a twin birth had compared with cows with a single birth. We observed associations of the dose-response type, such that when the milk fatto-protein ratio increased, the chance for pregnancy decreased, and as the somatic cell count increased, the chance for pregnancy decreased. In conclusion, factors that are known to affect reproductive efficiency also affect the chance of cows being pregnant at the herd VWP plus $30 \mathrm{~d}$.

Key words: reproductive performance, voluntary waiting period (VWP), dairy cow

\section{INTRODUCTION}

Reproductive performance in the dairy herd and the dairy cow is partly based on strategy decisions at the herd level; for example, when to serve the cow. These decisions may influence the outcome of individual cows; that is, when and if pregnancy will be achieved. The voluntary waiting period (VWP) is such a managerial decision factor. Reproductive performance in dairy cows is estimated and monitored by various measurements, such as the calving interval, conception rate, and number of inseminations. When monitoring and benchmarking reproductive performance, herd-specific factors such as delaying first service (Wapenaar et al., 2009) by designating a longer VWP may affect, for example, the calving interval. Comparing the calving interval between 2 cows (or the median between 2 herds) that have different VWP would lead to the conclusion that one cow (or herd) performs better than the other if this difference is not accounted for. The commonly used reproductive performance indicators reflect not only the biological reproductive performance of the cow, but also the managerial reproductive performance of the herd because they do not account for differences in VWP.

One way to control for different herd reproductive management strategies and to better reflect the biological reproductive performance of the cow is to use an indicator that controls for reproductive strategy 
decisions at the herd level. We previously investigated a herd reproductive performance indicator that was adjusted for herd VWP: proportion pregnant after the herd VWP plus $30 \mathrm{~d}$ (PV30) and found that it outperformed many other indicators (Löf et al., 2012). Such an indicator can also facilitate benchmarking between herds with different length of VWP. Many different factors are known to affect reproductive performance in dairy cows (Oltenacu et al., 1990; Butler, 2000; Fourichon et al., 2000; Roxstrom, 2001; Maizon et al., 2004; Windig et al., 2005; Bielfeldt et al., 2006; Garnsworthy et al., 2008; Simensen et al., 2010), but these associations are based on indicators that do not account for strategic decisions and it is not yet known if the same associations apply to PV30. The objective of this study was therefore to investigate factors affecting reproductive performance on the cow level measured with PV30.

\section{MATERIALS AND METHODS}

\section{Source of Data}

We used precollected data from the Cattle Database at the Swedish Dairy Association (Stockholm, Sweden). This database includes information on milk production from the Swedish Official Milk Recording Scheme at both the cow and herd levels and it combines data on pedigree, disease events, calving dates, inseminations, and pregnancy examinations. All cows that calved between July 1, 2008, and June 30, 2009, and originated from herds that had more than 50 milking cows on average were available for inclusion in the study. Cows also needed to come from herds comprising cows of at least 2 breeds (Swedish Red, Swedish Holstein, or other/crossbreed), the presence of at least $10 \%$ of one breed being sufficient for inclusion. Thus, 146,549 cows from 1,431 herds were included. Milk records from the Swedish Official Milk Recording Scheme for the first test-milking after calving was available for each cow, including milk yield $(\mathrm{kg})$, fat percentage, protein percentage, urea concentration ( $\mathrm{mmol} / \mathrm{L})$, and SCC (cells/ $\mathrm{mL}$ ). Data on how the cows were managed and housed, such as type of milking system and type of housing (pipeline with tiestall, parlors/rotaries with freestall, or automatic/robotic with free tall), feeding system (TMR or not specified), and organically managed (organic or not organic), were also available.

\section{Outcome Variable}

The reproductive performance indicator of interest was pregnancy at the herd VWP plus $30 \mathrm{~d}$ for each individual cow. The VWP for each of the 1,431 herds was estimated, using survival analysis, as the days postpartum by which $5 \%$ of the cows in the herd-year had received a first insemination. For 10 of the herds, it was not possible to calculate a VWP because there were few records of AI. Those herds were censored and removed from further analysis, which left 145,468 cows from 1,421 herds for further analysis. Conception and day of conception were based on information about inseminations/services, pregnancy checks, and calving dates. If day of conception occurred before the date for $\mathrm{VWP}+30 \mathrm{~d}$, the cow was recorded as pregnant at $\mathrm{VWP}+30 \mathrm{~d}(1)$; otherwise as nonpregnant (0).

Cows that were culled or left the herd before VWP +30 $\mathrm{d}$ were censored and removed from further analyses (n $=9,281$ ). Censoring was also done for cows where the pregnancy status at $\mathrm{VWP}+30 \mathrm{~d}$ could not be established; for example, because of no pregnancy checks or next calving ( $\mathrm{n}=2,943)$. Cows with unreasonably short intervals $(<20 \mathrm{~d})$ between calving and first AI were also censored $(\mathrm{n}=131)$ and cows with no records after calving were censored $(\mathrm{n}=392)$. In total, 132,721 cows were retained for analyses, of which 29,113 (22\%) were pregnant at $\mathrm{VWP}+30$. Of the nonpregnant cows, 81,483 cows had records of AI and 22,125 cows had no records of $\mathrm{AI}$.

\section{Predictor Variables}

Predictor variables are presented in alphabetical order. Breed was divided into 3 categories: Swedish Red (SRB), Swedish Holstein (SH), and other/crossbreeds.

Records from routine claw trimming that occurred in the interval between $50 \mathrm{~d}$ before calving and up to 180 DIM were used to classify claw status. Claw status was divided into 4 different categories: not in database, no problems at trimming, mild problems at trimming, and severe problems at trimming. Severe problems included laminitis-related conditions such as hemorrhages of the sole and the white line, sole ulcers, abscesses in the white line, white line disease, and double sole (Christer Bergsten, Swedish Dairy Association, Stockholm, personal communication).

Records of disease related to reproduction (e.g., cystic ovaries, anestrous, metritis/endometritis, and puerperal paresis) occurring between $10 \mathrm{~d}$ before calving up to 120 DIM were classified into 2 groups: no record of disease in one group and at least one record of disease in the other group. Records of disease other than reproduction (e.g., mastitis, ketosis, displaced abomasum, infections), occurring between $10 \mathrm{~d}$ before calving up to 120 DIM were classified into 2 groups: no record of disease in one group and at least one record of disease in the other group. Dystocia was defined as a record of a difficult birth, assisted calving, malposition and was classified into 3 categories: yes, no, and no information. 
Herds were also classified according to mean heat detection efficiency (HDE). The HDE was constructed as described below and was done according to principles described by Fetrow et al. (1990). From the VWP, 4 periods of $21 \mathrm{~d}$ (equivalent to 1 estrus period) were defined. A fifth period covered the VWP +85 d up to 200 DIM. Prebreeding estrus detection efficiency (PREDE) for periods 1 through 4 was calculated as the number of first AI during the period divided by the number of cows available for AI:

$$
\operatorname{PREDE} E_{w}=n_{w} / \sum_{w}^{5} n_{i}
$$

where $P R E D E_{w}=$ estrus detection efficiency in period $w$, and $n_{w}=$ number of cows inseminated in period $w$ $(w=1$ to 4$)$.

The PREDE of the herd was calculated as the mean of $\mathrm{PREDE}_{2}$ and $\mathrm{PREDE}_{3}$. Postbreeding estrus detection efficiency (PODE) was based on the interval between first and second AI, and was calculated as number of intervals of 18 to $24 \mathrm{~d}$ divided by number of intervals of 18 to 48 d. To create an overall HDE variable, PREDE and PODE were combined such that if the value of both PREDE and PODE was in the upper quartile, it was assigned $\mathrm{HDE}=3$. If either PREDE or PODE was in the upper quartile, it was assigned $\mathrm{HDE}=2$. If neither of PREDE or PODE was in the upper quartile, it was assigned $\mathrm{HDE}=1$. The calculation of PREDE and PODE was done for the herds and cows that remained after censoring as described in the previous section.

Two types of inseminations were present in the data: farmer performed (do-it-yourself, DIY) and AI-technician performed. In addition, data on natural service were available. A herd was classified as DIY AI or technician AI if more than $80 \%$ of the cows in the herd had inseminations of those types, or as mixed/bull otherwise. The reason for calculating this at the herd level was too many different combinations existed for individual cows.

The length of VWP was classified into 2 groups according to the median: $<51 \mathrm{~d}$ or $\geq 51 \mathrm{~d}$. The milk fat percentage was divided by the milk protein percentage to obtain the milk fat:protein ratio. Milking system and type of housing was divided in 3 groups: pipeline with tiestall, parlors/rotaries with freestall, or automatic/ robotic with freestall. Milk yield and fat:protein ratio were divided into 4 groups according to the 25th, 50th, and 75th percentiles. Organic was a dichotomous variable and was classified as yes when the herd was organically managed and no if the herd was not. Parity was classified according to the number of calvings the cow had had and was divided into 3 categories: first parity, second parity, and third and higher parities. Season was defined in 3 categories: winter-spring (January to April), summer (May to mid-September), or autumn-winter (mid-September to December). The cow was classified into one of these groups depending on when the date for VWP $+30 \mathrm{~d}$ occurred.

Somatic cell count was divided into 4 groups: $<100,000$ cells/mL, 100,000 to 200,000 cells/mL, 200,000-400,000 cells $/ \mathrm{mL}$, and $>400,000$ cells $/ \mathrm{mL}$. Total mixed ration was a dichotomous variable and was classified as yes if the herd used TMR and no if the herd did not or was not specified. Twin was a dichotomous variable: if the present calving resulted in a twin birth (or more), the cow was classified as twin $=1$ and otherwise twin $=$ 0 . Urea concentration was divided into 3 groups: $<2$ $\mathrm{mmol} / \mathrm{L}, 2$ to $6.5 \mathrm{mmol} / \mathrm{L}$, and $>6.5 \mathrm{mmol} / \mathrm{L}$ (Anders H. Gustafsson, Swedish Dairy Association, Stockholm, personal communication).

The distribution for the different predictor variables and the distribution of pregnant cows are shown in Table 1.

\section{Data Analysis}

All statistical analyses were performed using the software package SAS (version 9.2; SAS Institute, Cary, NC). Associations between the outcome variable and the predictor variables were first screened in univariable analyses using generalized estimation equations (GEE) that adjusted for the clustering of the data at the herd level. This was done using the GENMOD procedure with a binomial distribution, a logit link function and with the REPEATED statement subject $=$ herd. Ideally, generalized linear mixed models should have been used to better account for the actual covariance structure, but those models did not converge. Predictor variables with a $P$-value $\leq 0.20$ were considered for further analysis. Collinearity between variables was investigated by using Spearman rank correlation coefficients with the intention to drop one of the variables if the correlation was $\geq 0.6$ or $\leq-0.6$, but none was found. Next, a multivariable analysis was carried out and the associations between the outcome variable and the predictor variables were analyzed by GEE model as described above. Model building was by backward stepwise elimination of main effects with $P<0.05$ as the exclusion and re-entering criterion. Potential confounding was investigated by examining parameter changes in the estimates greater than $20 \%$, but no confounding was found. Biologically relevant interactions were subsequently added to the model and the backward stepwise elimination process was continued with $P<0.01$ as the exclusion and re-entering criterion. Parity interacted with almost all of the other 
LÖF ET AL.

Table 1. Distribution of cows for different predictor variables

\begin{tabular}{|c|c|c|c|}
\hline Predictor variable & Level & $\begin{array}{l}\text { Number of cows } \\
\text { at } \mathrm{VWP}^{1}+30\end{array}$ & $\begin{array}{c}\text { Proportion pregnant } \\
\text { at VWP }+30\end{array}$ \\
\hline \multirow[t]{3}{*}{ Breed } & Swedish Red & 51,670 & 0.24 \\
\hline & Swedish Holstein & 55,739 & 0.20 \\
\hline & Crossbred or other & 25,312 & 0.23 \\
\hline \multirow[t]{4}{*}{ Claw-trimming status } & Not in database & 74,541 & 0.21 \\
\hline & No problems at trimming & 29,270 & 0.24 \\
\hline & Mild problems at trimming & 10,703 & 0.24 \\
\hline & Severe problems at trimming & 18,207 & 0.22 \\
\hline \multirow[t]{2}{*}{ Disease related to reproduction } & No disease & 119,742 & 0.23 \\
\hline & Disease & 12,979 & 0.16 \\
\hline \multirow[t]{2}{*}{ Disease other than reproduction } & No disease & 124,252 & 0.22 \\
\hline & Disease & 8,469 & 0.15 \\
\hline \multirow{3}{*}{ Dystocia } & No information & 3,129 & 0.18 \\
\hline & No & 124,511 & 0.22 \\
\hline & Yes & 5,081 & 0.17 \\
\hline \multirow{3}{*}{ Heat detection efficiency ${ }^{2}$} & Low & 78,269 & 0.19 \\
\hline & Medium & 42,054 & 0.25 \\
\hline & High & 12,398 & 0.32 \\
\hline \multirow[t]{4}{*}{ Insemination type ${ }^{2}$} & Missing & 96 & 0.24 \\
\hline & Do-it-yourself AI & 71,255 & 0.23 \\
\hline & Technician & 41,380 & 0.22 \\
\hline & Mixed or bull & 19,990 & 0.20 \\
\hline \multirow[t]{2}{*}{ Length of $\mathrm{VWP}^{2}$} & Short $(<51 \mathrm{~d})$ & 69,923 & 0.20 \\
\hline & Long $(\geq 51 \mathrm{~d})$ & 62,798 & 0.23 \\
\hline \multirow{5}{*}{ Milk fat:protein ratio } & Missing & 2,724 & 0.19 \\
\hline & $<1.139$ & 32,767 & 0.24 \\
\hline & $1.139-1.257$ & 32,051 & 0.23 \\
\hline & $1.258-1.400$ & 31,967 & 0.22 \\
\hline & $>1.400$ & 33,212 & 0.20 \\
\hline \multirow{3}{*}{ Milking system $^{2}$} & Pipeline tiestall & 41,211 & 0.19 \\
\hline & Parlor or rotary freestall & 52,035 & 0.24 \\
\hline & Robotic freestall & 39,475 & 0.23 \\
\hline \multirow[t]{5}{*}{ Milk yield (kg) } & Missing & 2,724 & 0.19 \\
\hline & $<25.8$ & 32,228 & 0.22 \\
\hline & $25.8-31.7$ & 32,652 & 0.23 \\
\hline & $31.8-38.2$ & 32,199 & 0.22 \\
\hline & $>38.2$ & 32,919 & 0.20 \\
\hline \multirow[t]{2}{*}{ Organic $^{2}$} & Yes & 13,350 & 0.24 \\
\hline & No & 119,369 & 0.22 \\
\hline \multirow[t]{3}{*}{ Parity } & First & 50,733 & 0.24 \\
\hline & Second & 37,168 & 0.22 \\
\hline & Third and higher & 44,820 & 0.19 \\
\hline \multirow[t]{3}{*}{ Season } & Winter-spring & 48,819 & 0.22 \\
\hline & Summer & 42,729 & 0.20 \\
\hline & Autumn-winter & 41,173 & 0.24 \\
\hline \multirow[t]{5}{*}{$\mathrm{SCC}\left(\times 10^{3}\right.$ cells $\left./ \mathrm{mL}\right)$} & Missing & 2,724 & 0.19 \\
\hline & $<100$ & 77,282 & 0.23 \\
\hline & 100-199 & 19,786 & 0.22 \\
\hline & $200-400$ & 13,733 & 0.21 \\
\hline & $>400$ & 19,196 & 0.19 \\
\hline \multirow[t]{2}{*}{$\mathrm{TMR}^{2}$} & Yes & 20,036 & 0.22 \\
\hline & No & 112,685 & 0.22 \\
\hline \multirow[t]{2}{*}{ Twin } & Yes & 3,434 & 0.14 \\
\hline & No & 129,287 & 0.22 \\
\hline \multirow{4}{*}{ Urea $(\mathrm{mmol} / \mathrm{L})$} & Missing & 16,422 & 0.18 \\
\hline & $<2$ & 2,010 & 0.22 \\
\hline & $2-6.5$ & 106,725 & 0.23 \\
\hline & $>6.5$ & 7,561 & 0.21 \\
\hline
\end{tabular}

${ }^{1}$ Voluntary waiting period.

${ }^{2}$ The predictor variable was defined at the herd level.

predictors. To facilitate interpretation, we decided to stratify the analysis on parity. In the final models, all remaining effects were significant at $P<0.01$. To facilitate the interpretation of the results we derived a few "case cows," constructed as linear combinations of the estimated parameters (i.e., $\mathbf{L}^{\prime} \boldsymbol{\beta}$, where $\mathbf{L}$ is a vector of constants and $\boldsymbol{\beta}$ is a vector of point estimates from the model) and exponentiated to provide odds ratios (OR). 
Three case cows were derived by combining (1) high or low fat:protein ratio, (2) no record or with a record of reproductive disease, and (3) high or low SCC, with high or low milk yields, long or short VWP, and third or higher parity.

\section{RESULTS}

The results from the final GEE models are summarized in Table 2 where the specific OR can be found. Results are only reported when the main effect is significant; in some cases, individual levels within the main effects may have a confidence interval that overlaps 1 , indicating that the particular level did not have a significant association with the outcome even though the main effect did. The chance of pregnancy at VWP plus $30 \mathrm{~d}$ was higher for SRB and other/crossbreed cows than for SH cows. The difference between SRB and SH cows was greater for older cows than for first-parity cows. Claw trimming was not significant in the model for first-parity cows, so the results for claw trimming are only reported for cows of second and higher parities. The chance of pregnancy was lower for cows with severe problems at trimming than for cows with no problems at trimming. In addition, cows not included in the hoof trimming database had a lower chance of pregnancy than cows that had no problems at trimming. Cows with mild problems at trimming were not significantly different from cows with no problems at trimming.

Cows that had a record of disease related to reproduction had a lower chance of pregnancy than did cows without such a record. Cows that had a record of nonreproductive disease also had a lower chance of pregnancy than did cows without such a record. Second- and higher-parity cows with records of dystocia had a significantly lower chance of pregnancy than did cows with no record of dystocia.

As the milk fat:protein ratio increased, the chance of pregnancy declined, and this seemed to be the case for all parities. First-parity cows in the group with the highest milk yield had a lower chance of pregnancy than did first-parity cows in the group with the lowest milk yield. Second-parity cows in the 2 middle-yielding groups had a higher chance of pregnancy than did those in the lowest yielding group. Third- and higher-parity cows in all groups had a higher chance of pregnancy than did the group with the lowest milk yield.

Cows from herds with a long VWP (i.e., >51 d) had a higher chance of pregnancy than did cows from herds with a short VWP (i.e., <51 d). Cows held in freestalls had a higher chance of pregnancy than did cows in tiestalls.

The chance of pregnancy was lower in summer than in winter-spring (not significant for first-parity cows) and higher in autumn-winter than in winter-spring (not significant for second-parity cows). The higher the SCC in the milk, the lower the chance of pregnancy. Cows giving birth to twins had a lower chance of pregnancy than did cows with single births.

The results for the derived case cows are presented in Table 3. Cows with low milk fat:protein ratio, high milk yield, and belonging to a herd with long VWP had more than twice the chance $(\mathrm{OR}=2.2)$ of being pregnant at the VWP plus $30 \mathrm{~d}$ than did cows with a high milk fat:protein ratio, low milk yield, and short VWP. Additionally, cows with no record of reproduction-related disease, high milk yields, and long VWP had more than twice the chance for pregnancy than cows with a record of reproduction-related disease, low milk yield, and short VWP. The odds were also twice as high when comparing cows with low SCC, high milk yields, and long VWP with cows with high SCC, low milk yields, and short VWP.

\section{DISCUSSION}

We found that several factors affected the reproductive efficiency at the cow level even though we accounted for the herd's reproductive management in terms of the herd VWP. This may not be surprising, because many of the investigated predictor variables were not influenced by the farmers' decision when to start to inseminate after calving. We found associations of lower chance for pregnancy for many of the health deviations studied. Most of the findings are in agreement with what others have reported previously and will not be discussed further.

An intriguing observation in this study was that the pregnancy chance was higher for high-yielding cows of third and higher parities. Third and higher parity cows had about 50\% higher chance for pregnancy if their milk yield was in the highest group compared with cows in the group with low milk yields. This was also seen in the different combinations of case cows, where the cows with high milk yields always had higher odds for pregnancy compared with cows with low milk yields, and the odds were further increased in combinations with other positive effects (i.e., low milk fat:protein ratio, low SCC, or no record of reproductive disease). We also found that first-parity cows in the group with the highest milk yield had lower chance for pregnancy compared with first-parity cows in the group with the lowest milk yield. A fact that affects this relationship is that firstparity cows are less likely to belong to the highest milk yield group, because the quartiles were defined across parities. Even though the differences between the highest- and lowest-yielding groups for first-parity cows were statistically significant, this relationship is not re- 
waiting period (VWP) expressed as odds ratios (OR) with $95 \%$ CI

\begin{tabular}{|c|c|c|c|c|c|c|c|}
\hline \multirow[b]{2}{*}{ Predictor variable } & \multirow[b]{2}{*}{ Level } & \multicolumn{2}{|c|}{ Parity 1} & \multicolumn{2}{|c|}{ Parity 2} & \multicolumn{2}{|c|}{ Parity $\geq 3$} \\
\hline & & OR & $95 \% \mathrm{CI}$ & OR & $95 \% \mathrm{CI}$ & OR & $95 \%$ CI \\
\hline \multirow{3}{*}{ Breed } & Swedish Red & 1.15 & $1.08-1.21$ & 1.31 & $1.23-1.39$ & 1.32 & $1.23-1.41$ \\
\hline & Swedish Holstein & 1 & & 1 & & 1 & \\
\hline & Crossbred or other & 1.13 & $1.06-1.21$ & 1.25 & $1.16-1.34$ & 1.18 & $1.10-1.28$ \\
\hline \multirow[t]{4}{*}{ Claw-trimming data } & Not in database & -1 & 1.00 & 0.89 & $0.82-0.96$ & 0.88 & $0.81-0.95$ \\
\hline & No problems at trimming & - & - & 1 & & 1 & \\
\hline & Mild problems at trimming & - & - & 0.97 & $0.88-1.07$ & 1.02 & $0.91-1.13$ \\
\hline & Severe problems at trimming & - & - & 0.88 & $0.80-0.97$ & 0.83 & $0.76-0.92$ \\
\hline \multirow[t]{2}{*}{ Disease related to reproduction } & Disease & 0.81 & $0.74-0.9$ & 0.64 & $0.56-0.72$ & 0.76 & $0.70-0.81$ \\
\hline & No disease & 1 & & 1 & & 1 & \\
\hline \multirow[t]{2}{*}{ Disease other than reproduction } & Disease & 0.71 & $0.64-0.80$ & 0.74 & $0.65-0.84$ & 0.60 & $0.53-0.67$ \\
\hline & No disease & 1 & & 1 & $0.00-0.04$ & $\begin{array}{l}0.00 \\
1\end{array}$ & 0.000 .01 \\
\hline \multirow[t]{3}{*}{ Dystocia } & No information & 0.77 & $0.70-0.85$ & 0.9 & $0.70-1.15$ & 0.96 & $0.77-1.19$ \\
\hline & No & 1 & & 1 & & 1 & \\
\hline & Yes & 0.83 & $0.69-1.01$ & 0.78 & $0.66-0.93$ & 0.71 & $0.60-0.84$ \\
\hline \multirow[t]{3}{*}{ Heat detection efficiency ${ }^{2}$} & Low & 0.67 & $0.62-0.72$ & 0.70 & $0.65-0.75$ & 0.75 & $0.70-0.80$ \\
\hline & Medium & 1 & & 1 & & 1 & \\
\hline & High & 1.49 & $1.36-1.64$ & 1.36 & $1.21-1.52$ & 1.30 & $1.17-1.45$ \\
\hline \multirow[t]{2}{*}{ Length of $\mathrm{VWP}^{2}$} & Short $(<51 \mathrm{~d})$ & - & - & 1 & & 1 & \\
\hline & Long $(\geq 51 \mathrm{~d})$ & - & - & 1.20 & $1.12-1.29$ & 1.17 & $1.09-1.25$ \\
\hline \multirow[t]{4}{*}{ Milk fat:protein ratio } & $<1.139$ & 1 & & 1 & & 1 & \\
\hline & $1.139-1.257$ & 0.92 & $0.87-0.98$ & 1.01 & $0.94-1.08$ & 0.89 & $0.83-0.96$ \\
\hline & $1.258-1.400$ & 0.89 & $0.83-0.94$ & 0.91 & $0.84-0.98$ & 0.84 & $0.78-0.91$ \\
\hline & $>1.400$ & 0.79 & $0.75-0.85$ & 0.89 & $0.83-0.96$ & 0.80 & $0.74-0.86$ \\
\hline \multirow[t]{3}{*}{ Milking system ${ }^{2}$} & Pipeline tiestall & 1 & & 1 & & 1 & \\
\hline & Parlor or rotary freestall & 1.44 & $1.33-1.56$ & 1.31 & $1.21-1.42$ & 1.25 & $1.15-1.36$ \\
\hline & Robotic freestall & 1.42 & $1.31-1.54$ & 1.24 & $1.14-1.35$ & 1.19 & $1.09-1.3$ \\
\hline \multirow{4}{*}{ Milk yield (kg) } & $<25.8$ & 1 & & 1 & & 1 & \\
\hline & $25.8-31.7$ & 1.02 & $0.97-1.07$ & 1.13 & $1.02-1.24$ & 1.43 & $1.30-1.58$ \\
\hline & $31.8-38.2$ & 0.94 & $0.88-1.01$ & 1.13 & $1.03-1.25$ & 1.55 & $1.42-1.71$ \\
\hline & $>38.2$ & 0.74 & $0.64-0.84$ & 0.98 & $0.89-1.08$ & 1.51 & $1.37-1.66$ \\
\hline \multirow[t]{3}{*}{ Season } & Winter-spring & 1 & & 1 & & 1 & \\
\hline & Summer & 0.97 & $0.91-1.03$ & 0.78 & $0.73-0.83$ & 0.81 & $0.75-0.86$ \\
\hline & Autumn-winter & 1.19 & $1.13-1.26$ & 1.01 & $0.94-1.07$ & 1.07 & $1.00-1.14$ \\
\hline \multirow[t]{4}{*}{$\mathrm{SCC}\left(\times 10^{3}\right.$ cells $\left./ \mathrm{mL}\right)$} & $<100$ & 1.15 & & 1 & & 1.01 & \\
\hline & $100-199$ & 0.94 & $0.88-1$ & 0.95 & $0.88-1.02$ & 0.97 & $0.91-1.04$ \\
\hline & $200-400$ & 0.90 & $0.83-0.98$ & 0.92 & $0.85-1.00$ & 0.89 & $0.82-0.97$ \\
\hline & $>400$ & 0.87 & $0.81-0.94$ & 0.81 & $0.74-0.88$ & 0.78 & $0.72-0.84$ \\
\hline \multirow{2}{*}{ Twin } & Yes & 0.69 & $0.55-0.87$ & 0.73 & $0.62-0.86$ & 0.60 & $0.52-0.71$ \\
\hline & No & 1 & & 1 & & 1 & \\
\hline
\end{tabular}

${ }^{1}$ Nonsignificant effect excluded from the model.

${ }^{2}$ The predictor variable was defined at herd level. 
Table 3. Contrasted comparisons (case cows) constructed as linear combinations of the estimated parameters (i.e., $\mathbf{L}$ ' $\boldsymbol{\beta}$, where $\mathbf{L}$ is a vector of constants and $\boldsymbol{\beta}$ is a vector of point estimates from the model) from the generalized estimation equations models, exponentiated to provide odds ratios with $95 \%$ CI

\begin{tabular}{|c|c|c|}
\hline Comparison $^{1}$ & Odds ratio & $95 \%$ CI \\
\hline $\begin{array}{l}\text { Record of disease related to reproduction }+ \text { low milk yield }+ \text { short VWP }+ \text { parity } \geq 3 \\
\text { Low SCC }+ \text { high milk yield }+ \text { long VWP }+ \text { parity } \geq 3 \\
\text { vs. } \\
\text { High SCC }+ \text { low milk yield }+ \text { short VWP }+ \text { parity } \geq 3\end{array}$ & 2.26 & $1.99-2.58$ \\
\hline
\end{tabular}

ally relevant in the population as a whole because only a few animals are affected. Although a negative genetic correlation exists between milk yield and reproductive efficiency (Dematawewa and Berger, 1998; Roxstrom et al., 2001), results on phenotypic correlations in the literature are variable. Buckley et al. (2003b) reported that milk yield at first service was positively associated with the likelihood of pregnancy after $42 \mathrm{~d}$ of breeding. Gröhn and Rajala-Schultz (2000) found that the 60-d cumulative milk yield only minimally affected pregnancy and that the highest-yielding cows had slightly lower conception rate.

However, this difference between high- and lowyielding first-parity cows could depend on the fact that the farmer could make an active choice to allow high-yielding, first-parity cows a longer VWP, which would give them a lower chance for pregnancy at the herd VWP plus $30 \mathrm{~d}$ compared with low-yielding, firstparity cows, which might be inseminated at an earlier time. The same reasoning - that farmers make an active choice - can be applied to the third and higher parity cows, where a high-yielding cow would at lower risk for replacement than a low-yielding cow of third and higher parities. Eicker et al. (1996) demonstrated that high-yielding cows are more likely to be inseminated than low-yielding cows. We calculated the VWP for the herd as when $5 \%$ of the cows in that particular herd had received their first AI or service. A possible weakness in our study is that we did not estimate the VWP for each individual cow. By using the herd VWP as defined here, we assumed that most of the cows within a herd had largely the same VWP. It is possible, however, that some cows or groups of cows had longer or shorter VWP within that herd; that is, a large variability of the VWP might exist within the herd. This could then lead to the assumption that cows from herds with short VWP are less likely to become pregnant within $30 \mathrm{~d}$ from the VWP, but in fact, only a few cows had a short
VWP and the rest of the cows in that herd had long VWP. However, the analysis was done at the cow level, with the clustering at the herd level being handled in the model and cows were analyzed across herds. We previously investigated the correlation between the reported VWP and the calculated VWP and found an overall correlation of 0.51 (Löf et al., 2008), which is rather low and suggests that the reporting herdsmen either do not have a defined strategy or that the VWP is not strictly implemented, perhaps because of the use of VWP tailored to the individual cow. We have also seen (Löf et al., 2007a) that herds have reported shorter VWP for second- and higher-parity cows. Correct information about herd VWP would obviously be preferable to an estimated value, as used in this study, but such information is not easily collected and not necessarily always correct, as our results (Löf et al., 2008) indicate. Other farmer effects may also affect the reproductive performance of the cows, but these effects would most likely add to the random variation in the model and not likely to introduce bias.

In this study, cows from herds with long VWP had a greater chance for pregnancy at VWP $+30 \mathrm{~d}$ compared with cows that came from herds with short VWP. One reason for this could be that the cows from herds with long VWP have had sufficient time for involution and cleaning of the uterus and also time to establish ovarian activity. Darwash et al. (1997) showed that each additional interval of $21 \mathrm{~d}$ from the onset of luteal activity to the first insemination reduced the risk of failure of the insemination (nonpregnancy). Friggens and Labouriau (2010) found that the probability of pregnancy increased with an increasing number of observed estrus cycles and with an increased number of days between calving and first observed estrus.

A factor that we found to differ from common belief under Swedish conditions was that the chance for pregnancy was lower in summer compared with winter-spring 
(but not significantly so for first-parity cows) and that the chance was higher in autumn-winter compared with winter-spring (but not significantly so for second-parity cows). Our finding is contradictory to what was observed when using percentage 56-d nonreturn rates as a reproduction performance indicator, often used to visualize seasonal effects, where percentage nonreturn rate is approximately $15 \%$ higher in summer than in winter (Swedish Dairy Association, 2012). Refsdal (2007) also reported higher nonreturn rates at $60 \mathrm{~d}$ in summer months compared with winter months in Norway. The most likely explanation for the higher percentage nonreturn rate in summer is a lower estrous detection rate during summer when cows are on pasture. Missed heats will result in an increase in percentage nonreturn rate, which is incorrectly interpreted as better fertility. Pregnancy at VWP $+30 \mathrm{~d}$, which is based on the outcome of the insemination, is more likely to capture a "true" effect of season. Accordingly, de Vries and Risco (2005) showed that in the southeastern United States, pregnancy rates from 1976 to 2005 were consistently lower during summer than winter. The lower chance for pregnancy at VWP plus $30 \mathrm{~d}$ during the summer might be an effect of heat stress, which is known to severely impair fertility (Jordan, 2003), in addition to the effect of the cows being on pasture, resulting in a low heat detection rate.

Cows with a high milk fat:protein ratio ("dose") had lower chance for pregnancy ("response"), and we observed a "dose-response" relationship. When examining the case cows, the overall chance for pregnancy was further improved for a cow with low milk fat:protein when other positive factors were present $(\mathrm{OR}=2.20)$. Our results agree with those of Heuer et al. (1999) and Buckley et al. (2003b). Grieve et al. (1986) suggested that the milk fat:protein ratio could be used as an indicator for the lack of energy supply postpartum; that is, negative energy balance, because such a cow will mobilize body fat to meet energy needs, and the milk fat concentration then tends to increase and milk protein concentration tends to decrease. A cow in negative energy balance is known to have a reduced pregnancy rate (Butler, 2003). Our results show that the fat:protein ratio could be a good candidate to use to identify cows that are at risk of poor fertility and thus determine where preventive measures can be taken. Milk urea concentration has been used to estimate the protein:energy balance and is a tool to evaluate suboptimal feeding procedures. Reported associations between urea and reproductive performance have been inconsistent (Laven and Drew, 1999). Several researchers have reported negative associations between high levels of milk urea and reproductive performance (Gustafsson and Carlsson, 1993; Butler et al., 1996; Melendez et al., 2000).
We did not find any significant associations between milk urea and chance for pregnancy, nor did Godden et al. (2001), so more research to elucidate this relationship is probably needed.

Do-it-yourself AI was not found to be associated with the chance of pregnancy at VWP plus $30 \mathrm{~d}$, which is in contrast to our previous results (Löf et al., 2007b) and to the results of McCoy et al. (2006). However, Buckley et al. (2003a) recorded no difference between AI by technicians and DIY AI by farmers in terms of pregnancy rates with first inseminations in well-managed herds. In the model, we controlled for many factors, some of which might have co-varied with herds using DIY AI, even though we found no indications of collinearity between predictor variables. This could explain why DIY AI was not found to have significant effects at the cow level.

We previously discovered breed differences where herds of primarily SRB showed better reproductive performance compared with SH herds (Löf et al., 2007b). However, these breed comparisons were made across herds and the differences could have been due to between-herd differences in reproductive management. In the current study, we only included herds with at least 2 breeds and the comparison was thus within herd and should be more accurate. Additionally, the outcome (pregnant after the herd VWP plus $30 \mathrm{~d}$ ) eliminated some of the herd differences that could increase the breed effect. Despite these factors, we found that SRB cows had a higher chance of pregnancy than SH cows. We also found that the difference between the breeds became greater when comparing second- and higherparity cows to first-parity cows; that is, that the breed effect was more prominent in second- and higher-parity cows. Differences in reproductive efficiency between breeds were reported by Dillon et al. (2003), who compared 4 breeds, in which the Holstein-Friesian breed had lower pregnancy rate and longer calving to conception interval than the other breeds. These and our findings disagree with those of Friggens and Labouriau (2010), however, who did not find any differences in the probability for pregnancy between 3 Danish breeds. However, they did find differences in the rate of occurrence of first estrus, which was $30 \%$ greater for the Danish Red compared with the Danish Holstein.

In a previous study (Löf et al., 2007b), we found that herds with freestalls had a shorter calving interval (mean for the herd) compared with herds with tiestalls, which is in alignment with what we found in this study where cows in freestalls had higher chance for pregnancy. Thus, the previous observation is also valid on the cow level; that is, not only due to management differences, and is also in agreement with Petersson et al. (2006), who found a later resumption of ovarian cy- 
clicity in tied-housed cows compared with loose-housed cows.

Fertility is a complex trait and no single measure can tell the whole story. Traditionally, many reproductive management systems are based on visual detection of spontaneous estrus. The most difficult task for the farmer in such systems is to identify the first estrus and then to inseminate at an optimal time. As soon as one estrus is detected, it is easier to predict the next estrus. It is also during this time (the first ovulations after calving) that the most negative effect of negative energy balance on fertility occurs, a finding also supported by the association between fat:protein ratio and pregnancy at VWP+30 d. For the farmer and adviser, PV30 (Löf et al., 2012) is a valuable tool to improve the preinsemination reproductive efficiency; it combines both heat detection efficiency and conception rate (both critical components of the total calving interval) into one measure. In Sweden, PV30 has already been implemented in the AI recording system and is used by the farmer as a tool to improve fertility.

\section{CONCLUSIONS}

In this study, we tried to reduce some of the management effect on reproductive performance to obtain a truer estimation of biologically determined reproductive performance. First, our outcome - pregnant or not at the herd VWP plus $30 \mathrm{~d}$-was itself adjusted. Second, we included herd HDE and length of VWP in the statistical model to further adjust for herd differences. Despite adjusting for these factors, we still identified many of the associations that others have seen previously. In conclusion, we can verify that factors that are known to affect reproductive efficiency also affect the chance of cows being pregnant at the herd VWP plus $30 \mathrm{~d}$.

\section{ACKNOWLEDGMENTS}

This study was financially supported by The Swedish Farmers' Foundation for Agricultural Research (Stockholm, Sweden).

\section{REFERENCES}

Bielfeldt, J. C., K.-H. Tolle, R. Badertscher, and J. Krieter. 2006. Longevity of Swiss Brown cattle in different housing systems in Switzerland. Livest. Sci. 101:134-141.

Buckley, F., J. Mee, K. O'Sullivan, R. Evans, D. Berry, and P. Dillon. 2003a. Insemination factors affecting the conception rate in seasonal calving Holstein-Friesian cows. Reprod. Nutr. Dev. 43:543-555.

Buckley, F., K. O'Sullivan, J. F. Mee, R. D. Evans, and P. Dillon. 2003b. Relationships among milk yield, body condition, cow weight, and reproduction in spring-calved Holstein-Friesians. J. Dairy Sci. 86:2308-2319.
Butler, W. R. 2000. Nutritional interactions with reproductive performance in dairy cattle. Anim. Reprod. Sci. 60-61:449-457.

Butler, W. R. 2003. Energy balance relationships with follicular development, ovulation and fertility in postpartum dairy cows. Livest. Prod. Sci. 83:211-218.

Butler, W. R., J. J. Calaman, and S. W. Beam. 1996. Plasma and milk urea nitrogen in relation to pregnancy rate in lactating dairy cattle. J. Anim. Sci. 74:858-865.

Darwash, A. O., G. E. Lamming, and J. A. Woolliams. 1997. The phenotypic association between the interval to post-partum ovulation and traditional measures of fertility in dairy cattle. Anim. Sci. 65:9-16.

de Vries, A., and C. A. Risco. 2005. Trends and seasonality of reproductive performance in Florida and Georgia dairy herds from 1976 to 2002. J. Dairy Sci. 88:3155-3165.

Dematawewa, C. M. B., and P. J. Berger. 1998. Genetic and phenotypic parameters for 305-day yield, fertility, and survival in Holsteins. J. Dairy Sci. 81:2700-2709.

Dillon, P., S. Snijders, F. Buckley, B. Harris, P. O'Connor, and J. F. Mee. 2003. A comparison of different dairy cow breeds on a seasonal grass-based system of milk production. 2. Reproduction and survival. Livest. Prod. Sci. 83:35-42.

Eicker, S. W., Y. T. Grohn, and J. A. Hertl. 1996. The association between cumulative milk yield, days open, and days to first breeding in New York Holstein cows. J. Dairy Sci. 79:235-241.

Fetrow, J., D. McClary, R. Harman, K. Butcher, L. Weaver, E. Studer, J. Ehrlich, W. Etherington, W. Guterbock, D. Klingborg, J. Reneau, and N. Williamson. 1990. Calculating selected reproductive indices: Recommendations of the American Association of Bovine Practitioners. J. Dairy Sci. 73:78-90.

Fourichon, C., H. Seegers, and X. Malher. 2000. Effect of disease on reproduction in the dairy cow: A meta-analysis. Theriogenology 53:1729-1759.

Friggens, N. C., and R. Labouriau. 2010. Probability of pregnancy as affected by oestrus number and days to first oestrus in dairy cows of three breeds and parities. Anim. Reprod. Sci. 118:155-162.

Garnsworthy, P. C., K. D. Sinclair, and R. Webb. 2008. Integration of physiological mechanisms that influence fertility in dairy cows. Animal 2:1144-1152.

Godden, S. M., D. F. Kelton, K. D. Lissemore, J. S. Walton, K. E. Leslie, and J. H. Lumsden. 2001. Milk urea testing as a tool to monitor reproductive performance in Ontario dairy herds. J. Dairy Sci. 84:1397-1406.

Grieve, D. G., S. Korver, Y. S. Rijpkema, and G. Hof. 1986. Relationship between milk composition and some nutritional parameters in early lactation. Livest. Prod. Sci. 14:239-254.

Gröhn, Y. T., and P. J. Rajala-Schultz. 2000. Epidemiology of reproductive performance in dairy cows. Anim. Reprod. Sci. 6061:605-614.

Gustafsson, A. H., and J. Carlsson. 1993. Effects of silage quality, protein evaluation systems and milk urea content on milk yield and reproduction in dairy cows. Livest. Prod. Sci. 37:91-105.

Heuer, C., Y. H. Schukken, and P. Dobbelaar. 1999. Postpartum body condition score and results from the first test day milk as predictors of disease, fertility, yield, and culling in commercial dairy herds. J. Dairy Sci. 82:295-304.

Jordan, E. R. 2003. Effects of heat stress on reproduction. J. Dairy Sci. 86(E-Suppl.):E104-E114.

Laven, R. A., and S. B. Drew. 1999. Dietary protein and the reproductive performance of cows. Vet. Rec. 145:687-695.

Löf, E., U. Emanuelson, and H. Gustafsson. 2007a. Voluntary waiting period-Do dairy farmers make an active choice? Page 12 in Proc. Int. Conf. Fertility in Dairy Cows: Bridging the Gaps, Liverpool Hope University, UK. University of Liverpool, Leahurst, UK.

Löf, E., U. Emanuelson, and H. Gustafsson. 2008. A new reproductive performance indicator for dairy herds adjusted for voluntary waiting period . Reprod. Domest. Anim. 43(Suppl. 3):50.

Löf, E., H. Gustafsson, and U. Emanuelson. 2007b. Associations between herd characteristics and reproductive efficiency in dairy herds. J. Dairy Sci. 90:4897-4907. 
Löf, E., H. Gustafsson, and U. Emanuelson. 2012. Evaluation of two dairy herd reproductive performance indicators that are adjusted for voluntary waiting period. Acta Vet. Scand. 54:5.

Maizon, D. O., P. Oltenacu, Y. Gröhn, R. Strawderman, and U. Emanuelson. 2004. Effects of diseases on reproductive performance in Swedish Red and White dairy cattle. Prev. Vet. Med. 66:113-126.

McCoy, M. A., D. R. Mackey, A. W. Gordon, B. W. Kennedy, H. W. J. Edgar, and C. S. Mayne. 2006. Fertility results after do-it-yourself and commercial company artificial insemination in dairy herds in Northern Ireland. Vet. Rec. 159:119-121.

Melendez, P., A. Donovan, and J. Hernandez. 2000. Milk urea nitrogen and infertility in Florida Holstein cows. J. Dairy Sci. 83:459-463.

Oltenacu, P. A., A. Frick, and B. Lindhe. 1990. Epidemiological study of several clinical diseases, reproductive performance and culling in primiparous Swedish cattle. Prev. Vet. Med. 9:59-74.

Petersson, K.-J., E. Strandberg, H. Gustafsson, and B. Berglund. 2006. Environmental effects on progesterone profile measures of dairy cow fertility. Anim. Reprod. Sci. 91:201-214.

Refsdal, A. O. 2007. Reproductive performance of Norwegian cattle from 1985 to 2005: Trends and seasonality. Acta Vet. Scand. 49:5.

Roxstrom, A. 2001. Genetic aspects of fertility and longevity in dairy cattle. Doctoral Thesis. Department of Animal Breeding and Ge- netics, Swedish University of Agricultural Sciences, Uppsala, Sweden.

Roxstrom, A., E. Strandberg, B. Berglund, U. Emanuelson, and J. Philipsson. 2001. Genetic and environmental correlations among female fertility traits and milk production in different parities of Swedish red and white dairy cattle. Acta Agric. Scand. A Anim. Sci. 51:7-14.

Simensen, E., O. Osteras, K. Boe, C. Kielland, L. Ruud, and G. Naess. 2010. Housing system and herd size interactions in Norwegian dairy herds; associations with performance and disease incidence. Acta Vet. Scand. 52:14.

Swedish Dairy Association. 2012. Cattle Statistics 2010/2011. Swedish Dairy Association, Eskilstuna, Sweden.

Wapenaar, W., M. Green, J. Huxley, J. Reader, A. Biggs, M. Burnell, J. Breen, J. Husband, J. Statham, M. Thorne, and B. May 2009. Measuring and comparing reproductive performance in dairy herds: Strengths and weaknesses of frequently used parameters. Livestock 14:36-42.

Windig, J. J., M. P. L. Calus, and R. F. Veerkamp. 2005. Influence of herd environment on health and fertility and their relationship with milk production. J. Dairy Sci. 88:335-347. 